\title{
The Effects of Strategic Orientation, Technology Innovation, and Business Strategy in Improving Business Performance of Sme of Fashion Industry in Jakarta
}

\author{
Siti Maemunah, Asep Hermawan, Hotniar Siringoringo \\ Trisakti University, Jakarta \\ willy.arafah@gmail.com
}

\begin{abstract}
Small and Medium Enterprise (SME) plays a key role in actualizing the Indonesian economic growth. Job opportunities, tax contribution, export business, and import revenue facilitate the distribution of commodities and help develop the human resources. This research aims to unveil the effects of strategic orientation, technology innovation, and business strategy in improving business performance of SME of fashion industry in Jakarta. The data was collected from questionnaires distributed to 250 respondents. The data was analyzed with structural equation modeling (SEM) and processed with LISREL 8.8. The result of this research proves that strategic orientation plays a positive in business strategy. Based on such finding, it is concluded that ways to sustain and increase the effectivity of strategic orientation are to collect information regarding customers' needs and desires, to agree upon a commitment from all decision makers and employees to satisfy customers, and to improve business performance. By technology innovation, old-design products can have new designs which meet the market's expectation and are qualified. Also, the process innovation is effective to make business performance even better. Business strategy has to assure the ability of fast-handling in order to improve business performance, especially in tough situation such as internal and external threats. For every sold unit, business performance will improve.
\end{abstract}

\section{INTRODUCTION}

SME basically triggers innovation and the birth of local entrepreneurs. It bears a prominent role in Indonesian Economy, especially in 1997's economic crisis strike and in 2008's global crisis. Such problems necessitate the improvement of sustainable power of competitiveness in order to survive in fluctuating circumstances and among businesses' rivalry which grows fiercer and more uncertain (Rostek, 2012; Ada et al., 2013). To upgrade business performance, strategic orientation becomes the main reference for companies to cultivate the righteous strategic behavior (Altuntaset al., 2013). Kanchanda (2011) explains that applying business strategy opens the opportunities for companies to reach sustainable competitive advantage. Under intense competition and unpredictable business environment, business strategy with the support of internal business competence will help business performance itself (Hadiet al., 2015). Technology innovation benefits SME of fashion industry through its productivity, innovation, and global competitiveness (Mesmer-Magnus and DeChurch, 2009; Laforet, 2009) and grows the business itself (Anantatmula\&Kanungo, 2010; Soto-Acosta, et al. 2010a; Soto-Acosta et al. 2010b; Soto-Acosta et al. 2015; Palacios-Marquéset al., 2015)

\section{RESEARCH PROBLEM}

The current research raises some crucial issues which are listed as the following: (1) does strategic orientation have any effects towards business strategy?; (2) do strategic orientation, technology innovation, and business strategy have any effects towards business performance? 
The Effects of Strategic Orientation, Technology Innovation, and Business Strategy in Improving Business Performance of Sme of Fashion Industry in Jakarta

\section{LITERATURE REVIEW}

The main purpose of strategic management is to predict and interpret companies' performances (Morgan and Strong, 2003). Identification of competitive strategy is known as strategic choice or strategic orientation. Strategic orientation is made to nurture the proper strategic behavior in an organization and is aimed at reaching excellent performance (Gatingnon and Xuereb, 1997). Strategic orientation is used to anticipate uncertainty in an environment, so that internal corporate resource strategy (RBV) and the external forces fit one another (Porter, 1980). Market orientation focuses on values which promote market-consistent behavior, such as customer orientation, competitor orientation, and inter-functional coordination (Narver\& Slater, 1990; Altuntaşet al., 2013; Kirca, 2011; Al-Mohammad, 2010; Tutaret al., 2015). Companies need market orientation, learning orientation, and entrepreneur orientation (Bhuianet al., 2005). Companies should be able to learn, innovate, be proactive, and be aggressive in facing competition, be it marketing competition or quality competition. Entrepreneur orientation is a company's ability to increase proactive managers (in risk-taking and innovation competence) in order to achieve technology innovation (Carmen et al., 2010; Li et al., 2011). Employee orientation acts as a company's future-success determiner, by deciding an infestation and improving employees' responsibility towards their companies (Harris and Ogbonna, 2001; Piercy et al., 2002).

Defined technology innovation is about developing new knowledge to keep consumers and to produce and sell products and processes (new services) through commercialization (Pearce, et al., 2013). Technology innovation can help companies who are currently facing national or global competition. It develops new knowledge as a basis to maintain consumers (Freeman and Soete 1997).

Defined business strategy is a power of competitiveness which preserve scarce resources, yields business products and processes, and makes economic profit. Better quality can also improve performance and innovation (Yang et al. 2015). Business strategy makes profit based on lower expense, improved quality, new products, and innovative and excellent performance.

Business performance is the achievement gained by an organization for doing activities within certain period of time (Gatingnon and Xuereb, 1997). Performance is a reflection of a company's success. Business performance is a work achievement (Yang et al. 2015)and is an accumulation of all organizational units. According to Voss and Voss (2000), work indicator comprises of several factors: the fulfillment of sales target, the number of customers, year-to-year sales growth, market reach, and profit increase. Imoleayo (2010) believes that a sale's price and a sale's income also indicate performance.

\section{RESEARCH METHODS}

This research uses testing hypothesis as a design. There are four variables which are taken in the measurement: strategic orientation, technology innovation, business strategy, and business performance. All variables are measured with 5 points of Likert Scale, which comprise of: 5 points for "strongly agree"; 4 points for "agree"; 3 points for "quite agree"; 2 points for "disagree"; 1 point for "strongly disagree". Categories of respondents involved in this questionnaire, from gender, age, to occupational status.

\section{RESULT AND DISCUSSION}

This research found that strategic orientation gives positive and significant effects towards business strategywith $\mathrm{t}$-value 6.09 ( $\mathrm{t}$-value $\geq 1,96$ ). This research found that technology innovation has positive and significant effects towards business strategy with $\mathrm{t}$-value 4.26 ( $\mathrm{t}$-value $\geq 1,96$ ). This research found that strategic orientation has positive and significant effects towards business performance with t-value 2.01 ( $t$-value $\geq 1,96$ ). This research 
The Effects of Strategic Orientation, Technology Innovation, and Business Strategy in Improving Business Performance of Sme of Fashion Industry in Jakarta

found that technology innovation has positive and significant effects towards business performance with t-value 3.94 ( $t$-value $\geq 1,96$ ). This research found that business strategy has positive and significant effects towards business performance with $\mathrm{t}$-value 7.70 ( $\mathrm{t}$-value $\geq 1,96$ ).

\section{CONCLUSION}

This research found that strategic orientation and technology innovation give positive effects to business strategy and have a strong correlation with SME of fashion industry business performance. Ways to improve strategic orientation include: collecting information regarding customers' needs and desires, agreeing upon a commitment from all decision makers and employees to satisfy customers and to improve performances. Ways to improve technology innovation include: developing new products which increases the growth of companies in outside-patents sectors, developing new products which encourages the growth of companies, having a solid commitment to increase performances. Ways to improve business strategy include: seizing the opportunities and immediately responding to external and internal threats, doing company's business strategy in facing dynamic and unpredictable business environment.

\section{REFERENCES}

1. Ada, E., Kazancoglu, Y., \&Sagnak, M. (2013). Improving Competitiveness of Small and Medium-Sized Enterprises (SMEs) in Agriproduct Export Business Through ANP: The Turkey Case. Agribusiness, 29(4), 524-537, http://dx.doi.org/10.1002/agr.21320.

2. Altuntaş, G., Semercioz, F. \&Eregez, H. (2013). Linking strategic orientations to organizational performance: the role of innovation in private healthcare organizations. Procedia-Social and Behavioral Sciences, 99, 413-419.

3. Anantatmula, V.S., \&Kanungo, S. (2010). Modeling enablers for successful KM implementation. Journal of Knowledge Management, 14(1), 100113.

4. Bhuian, S. N., Menguc, B., \& Bell, S. J. (2005). Just entrepreneurial enough: the moderating effect of entrepreneurship on the relationship between market orientation and performance. Journal of Business Research, 58(1), 9-17.

5. Gatignon, H. and Xuereb, J.M. (1997). Strategic orientation of the firm and new produck performance. Journal of Marketing Research, Vol. 34: 77 - 90.

6. Hadi, N., Abdullah, N. and Sajilan, S. (2015). Conceptual Framework of Factors Affecting SMEs Manufacturing Business Performance. Research (www.sibresearch.org) ISSN: 2304-1013Rev. Integr. Bus. Econ. Res. Vol 4(3) 250.

7. Harris, L.C., \&Ogbonna, E. (2001). Strategic human resource management, market orientation, and organizational performance. Journal of Business Research, 51, 157-66

8. Kanchanda, K. (2011). Organizational Flexibility Capability, Inovation Advantage and Firm Sustainability: Evidence from Electronic Manufacturing Businesses in Thailand: International Journal of Business Strategy, ISSN: 1553-9563.

9. Kirca, A. (2011). The effect of market orientation on subsidiary performance: Empirical evidence from MNCs in Turkey. Journal of World Business, 46, 447-454. 
The Effects of Strategic Orientation, Technology Innovation, and Business Strategy in Improving Business Performance of Sme of Fashion Industry in Jakarta

10. Imoleayo, F. O. (2010). The Impact of Product Price Changes on the Turnover of Small and Medium Enterprises in Nigeria. Journal brand Broad Research in Accounting, Negotiation, and Distribution. Vol. 1. p. 60-79.

11. Pearce II, J. A. and Robinson, R. B. (2013). Strategic Management Planning for Domestic \& Global Competition. Thirteenth Edition. McGraw-Hill.

12. Porter. M.E. (1980). Competitive Strategy, Free Press, New York. NY.

13. Rostek, K. (2012). The reference model of competitiveness factors for SME medical sector. Economic Modelling, 29(5), 2039-2048. doi:10.1016/j. econmod.2012.03.002

14. Voss, B.G. and Voss, Z.G. (2000). Strategic orientation and firm performance in an artistic environment. Journal of Marketing, Vol. 64 No. 1, pp. 67-83.

15. Yang, M., Kueng, L. and Hong, B. (2015). Business Strategy and the Management of Firms. University of Washington.

Citation: Siti Maemunah, Asep Hermawan, Hotniar Siringoringo. "The Effects of Strategic Orientation, Technology Innovation, and Business Strategy in Improving Business Performance of Sme of Fashion Industry in Jakarta." American Research Journal of Business and Management. 2018; 4(1): 1-4.

Copyright (c) 2018 Siti Maemunah, Asep Hermawan, Hotniar Siringoringo. This is an open access article distributed under the Creative Commons Attribution License, which permits unrestricted use, distribution, and reproduction in any medium, provided the original work is properly cited. 